\title{
Are we predisposed to type 2 diabetes risk: a case- control study from urban population in western India
}

\begin{abstract}
Background: Type 2 diabetes mellitus (T2DM) is driven by genetic and environmental factors. Sequence variants of candidate genes are known to predispose Indians to T2DM. 'Asian Indian Phenotype' is a cluster of abnormality described earlier; links possible genetic proneness of Indians. PPAR $\gamma 2$ gene SNP rs1801282, a missense variant is associated with improved insulin sensitivity, reduced T2DM risk and adipogenesis. This polymorphism does not confer this benefit to Indian Asians as seen in Caucasians. ADR $\beta 3$ gene SNP rs4994 produce variant receptor protein with altered affinity; is associated to development of dyslipidemia, obesity, insulin resistance (IR) and early T2DM onset. Combined influence of both these alleles on hemoglobin glycation, insulin resistance and dyslipidemia is not reported which is addressed in this case-control study from urban western Indian population.
\end{abstract}

Methods: T2DM subjects ( $\mathrm{n}=506)$ and non-diabetic controls $(\mathrm{n}=544)$ largely from urban Hindu community were enrolled through consecutive sampling and studied for fasting plasma glucose (FPG), glycosylated hemoglobin (HbAlc), fasting insulin (FI), HOMA-IR, total cholesterol (TC), triglyceride (TG) and high-density lipoprotein cholesterol (HDL-C), Low-density lipoprotein cholesterol (LDL-C) and non-HDL-C through biochemical methods. SNPs were studied with restriction fragment length polymorphism (RFLP). Statistical analysis performed by Statav12 and IBM-SPSS included a variety of tests.

Results: T2DM subjects had higher FPG, HbAlc, HOMA-IR, TG and lower FI, HDL-C, LDL-C as compared to non-diabetic healthy individuals, while no differences in TC and non-HDL-C were seen in subgroups. The frequencies of reference and variant alleles of rs1801282 of PPAR $\gamma 2$ and rs4994 of ADR 33 individually were similar in T2DM and controls. PPAR $\gamma 2$ ref allele bearing T2DM subjects had a higher HbA1c and HOMA-IR in dyslipidemic as well as non-dyslipidemic than PPAR $\gamma 2$ variant allele bearing counterpart. On allelic combination, presence of PPAR $\gamma 2$ ref + ADR $\beta 3$ va was associated with high $\mathrm{HbA} 1 \mathrm{c}$ and dyslipidemia than PPAR $\gamma 2 \mathrm{va}+\mathrm{ADR} \beta 3$ ref allelic type. Taken together, reference allele of PPAR $\gamma 2$ plus variant ADR $\beta 3$ allelic type is likely to predispose to higher $\mathrm{HbA1c}$, HOMA-IR and dyslipidemia.

Conclusion: Coexistence of reference allele of PPAR $\gamma 2$ gene and variant allele of ADR $\beta 3$ gene, dyslipidemia and obesity in an individual is likely to confer increased insulin resistance thereby increasing susceptibility to the development of T2DM.

Keywords: type 2 diabetes mellitus, HbA1c, dyslipidemia, PPAR $\gamma 2$, ADR $\beta 3$
Volume 5 Issue 3 - 2017

\author{
Jayesh J Sheth,' Sunil Trivedi,' Ankna Shah,' \\ Nutan Nabar,' Navneet Shah, ${ }^{3}$ Premal \\ Thakor, ${ }^{4}$ Rama Vaidya, ${ }^{2}$ Frenny Sheth' \\ 'Department of Biochemistry and Molecular Genetics FRIGE, \\ India \\ ${ }^{2}$ Endocrine and Metabolic Disorders, Kasturba Health Society, \\ Medical Research Centre, India \\ ${ }^{3}$ Department of Diabetes and Endocrinology, Sterling Hospital, \\ India \\ ${ }^{4}$ Gujarat Diabetic Association, India
}

Correspondence: Jayesh J Sheth, Department of Biochemistry and Molecular Genetics, FRIGE, s Institute of Human Genetics, FRIGE House, Jodhpur Gam Road, Satellite, Ahmedabad 3800 I5, India, Tel +91 79-26921414, Email jshethad @gmail.com

Received: July 12, 2017| Published: August II, 2017
Abbreviations: T2DM, type 2 diabetes mellitus; $P P A R \gamma 2$, peroxisome proliferator-activated receptor $\mathrm{g} 2$; $A D R \beta 3$, beta-3adrenergic receptor; IR, insulin resistance; FPG, fasting plasma glucose; HbAlc, glycosylated hemoglobin; FI, fasting insulin; HOMA-IR, homeostatic model assessment insulin resistance; TC, total cholesterol; TG, triglyceride; HDL-C, high-density lipoprotein cholesterol; LDL-C, low-density lipoprotein cholesterol; RFLP, restriction fragment length polymorphism; WHR, waist to hip ratio; SNP, single nucleotide polymorphism

\section{Introduction}

Type 2 diabetes mellitus (T2DM; OMIM 125853) is a complex metabolic disease triggered by the influence of numerous genetic and environmental factors. ${ }^{1,2}$ Several studies have addressed the role of sequence variants of specific candidate genes. ${ }^{3,4}$ Radha \& Mohan, ${ }^{5,6}$ emphasized on a higher genetic predisposition of Indians to T2DM. Indians are reported to have a higher plasma insulin (compared to matched Europeans), ${ }^{7}$ a higher WHR (waist to hip ratio) for any given BMI (compared to other ethnic groups). ${ }^{8}$ and a greater insulin resistance (IR). Compared to other ethnic groups. ${ }^{9-11}$ Studies on migrant Indians have also shown a higher prevalence of T2DM (compared to indigenous population). ${ }^{12-14}$ Collectively, these studies point towards possibility of genetic proneness (genetic predisposition) of Indians to T2DM. In addition, fat tends to accumulate more in the abdominal region in Indians and therefore may be more prone to develop insulin resistance. ${ }^{10,15}$ This cluster of metabolic abnormality is collectively referred to as 'Asian Indian Phenotype'. ${ }^{16}$

$P P A R \gamma 2$, a candidate gene is predominantly expressed in adipose tissue and plays a vital role in insulin action and glucose homeostasis. ${ }^{17,19}$ Moreover, it also act as a 'fatty acid sensor' with affinity towards free fatty acids..$^{20,21}$ SNP rs1801282 in the PPAR 2 gene is a missense variant associated with improved insulin sensitivity, decreased risk of T2DM and adipogenesis; thus suggesting its role in glucose deregulation, dyslipidemia and obesity. ${ }^{17,18,20}$ Furthermore, a recent meta-analysis of 41 studies showed that the presence of this variant allele was associated with T2DM (Meta-analysis; OR=0.79, 
$95 \% \mathrm{CI}=0.66-0.95, \mathrm{I} 2=69 \%$ ) implicating its role in disease risk. ${ }^{22}$ In addition, the Ala allele of this polymorphism was associated with a decreased risk of type 2 diabetes. ${ }^{23}$ Moreover, Radha et al concluded that despite the frequency of the Ala allele at the PPARg-Pro12Ala locus was the same in individuals of South Asian descent, as in Caucasians, this polymorphism does not appear to improve insulin sensitivity or decrease risk for type 2 diabetes in South Asians (Asian Indians), as it does in Caucasians. ${ }^{5}$

Likewise, $A D R \beta 3$ is primarily expressed in adipose tissue and is implicated in lipolysis regulation. ${ }^{24}$ SNP rs4994 of this gene is a missense variant that produces a protein (receptor) with altered affinity to norepinephrine..$^{24}$ Additionally, this variant has been shown to have an altered interaction with G-protein coupled receptors in adipocytes that may promote decrease in lipolysis resulting into development of dyslipidemia, obesity, insulin resistance (IR) and an earlier onset of T2D. ${ }^{24,25}$ This may likely to be due to its influence on the glucose and lipid metabolism. However, inconsistent results on the association between the above variant alleles and T2DM risk may likely be due to the studies being carried out in individuals of different ethnicity. ${ }^{24,26}$ The ADRB3 rs4994 polymorphism however, is reported to be associated with T2DM from Mexico city. ${ }^{27}$ Moreover, Several past studies have connected this non-synonymous rs4994 polymorphism to T2DM, obesity, insulin resistance and hypertension..$^{28-31}$

Despite the availability of the association results with aforementioned variants for several ethnicity. ${ }^{18,19,25,26}$ no study has been reported the association between these variant alleles and T2DM in the western Indian population. Interestingly, interactions of alleles of PPAR 2 (Pro12Ala) and ADRB3 (Trp64Arg) have been found to be related to obesity risk in Spanish children and adolescents as well as Mexican-American adults. ${ }^{32,33}$

The current study takes into account the synergism of polymorphisms of (Pro12Ala in PPAR 2 and Trp64Arg in ADRB3) and aim to catch their influence on genetic proneness in a case-control study in largely Hindu urban Western Indian population by juxtaposing them to hemoglobin glycation, insulin resistance and dyslipidemia.

\section{Materials and methods}

\section{Study population}

A total of 1050 subjects were recruited for the study with 506 T2DM cases and 544 non-diabetic healthy controls from western India. They were enrolled after informed consent by consecutive sampling technique during April, 2012 to December, 2014 from the out-patient departments of several diabetes clinics and through weekly camps at two institutes (FRIGE, Ahmedabad and KHS's Medical Research Centre, Mumbai).The study were approved by the institutional Ethics committees of the institutions. The study participants were largely from Hindu community. The inclusion criteria for T2DM subjects were (a) age ( $\geq 25$ years); (b) duration of diabetes ( $\geq 6$ months from the date of diagnosis) and; (c) fasting plasma glucose levels (FPG $\geq 126.0 \mathrm{mg} /$ dl). Non-diabetic healthy controls were recruited with an inclusion criterion of (a) age ( $\geq 25$ years); (b) HbA1c level $\leq 6.5 \%$ and; (c) fasting plasma glucose levels $(\mathrm{FPG} \leq 110.0 \mathrm{mg} / \mathrm{dl})$. Subjects with Type 1 Diabetes, lactating and pregnant mothers, and those with concomitant chronic illness were excluded from the study.

\section{Epidemiological questionnaire and sample collection}

Each participant completed a standardized baseline questionnaire in person at each institute. The questionnaire included medical history, family history and demographic data. Blood samples were collected in fluoride, serum and EDTA vaccutainers in the morning (0800-1100hrs) after 12 hours fasting for biochemical analysis. fasting plasma glucose (FPG), glycosylated hemoglobin (HbA1c), fasting insulin (FI), insulin resistance by HOMA-IR and lipid profile and SNP genotyping. Serum samples were separated within 30-45minutes of collection and stored at $-20^{\circ} \mathrm{C}$ till further analysis.

\section{Biochemical investigations}

FPG and lipid profile including total cholesterol (TC), triglyceride (TG) and high-density lipoprotein cholesterol (HDL-C) were measured by colorimetric method with respective calibrator and biological standards by commercially available kits using an autoanalyzer BTS 330 (Biosystem, Spain)]. HbA1c was determined using affinity assay. NycoCard reader-II (Axis-Shield, Norway) from whole blood. Serum FI levels were measured by Immuno Radiometric Assay. using commercial kit (Immunotech, France) with $\gamma$-counter system PC-RIA MAS (Stratec Biometrical System AG, Germany). Insulin resistance was calculated by the Homeostasis Model of Assessment-Insulin Resistance Index (HOMA-IR). ${ }^{34}$ Low-density lipoprotein cholesterol (LDL-C) and non-HDL-C were calculated by standard formula. LDL=TC-HDL-C-(TG/5) and non-HDL-C=TCHDL-C. The intra-assay coefficients of variation for lipid parameters were $\mathrm{TC}=1.39 \%, \mathrm{TG}=0.50 \%$ and $\mathrm{HDL}-\mathrm{C}=1.67 \%$ whereas inter-assay coefficients of variations for aforementioned lipid parameters were $2.65 \%, 1.65 \%$ and $4.69 \%$ respectively.

\section{SNP genotyping}

Genomic DNA was extracted from whole blood by salting out method. ${ }^{35}$ SNP rs 1801282 and rs4994 were genotyped using restriction fragment length polymorphism (RFLP) PCR. The detailed PCR conditions are mentioned in supplementary Table 1 . The amplified and digested PCR products were separated on 3\% agarose gel and visualized under UV light based E-Gel imager (Life technologies, USA).

\section{Statistical analysis}

The sample size (current study) yielded a margin error of 5\% and confidence limit of $95 \%$ with an on-line calculator. ${ }^{36} \mathrm{HbAlc}$ values were mentioned as percentage of total hemoglobin and all other biochemical parameters were expressed as $\mathrm{mg} / \mathrm{dl}$. Student's t-test was conducted to compare the distribution of continuous variables between cases and controls. Correlation between the SNP, HbA1c and HOMA-IR was carried out using least squares linear regression. Hardy-Weinberg equilibrium (HWE) test for SNPs was performed in controls. Comparison of allele frequencies of SNPs between populations was carried out using Fisher's exact test. Binomial logistic regression was performed to yield odds ratios (ORs). ROC analysis to establish the cut-offs for HOMA-IR was performed in the study population. The significance threshold for two-sided type 1 error (P-value) in all tests was set at 0.05 . False positive error/Type I error rate was 0.05 . All statistical analysis was carried out in Stata v12. for Macintosh OS (Stata Corp., College Station, USA) and IBMSPSS v19.0.

The cut-offs used for all the parameters for regression analysis were as follow: $\mathrm{HbA} 1 \mathrm{c}>7 \%$ in T2DM subjects and $\leq 5.7 \%$ in nondiabetic control subjects. ${ }^{37}$ HOMA-IR of $\leq 3.95$ were considered as normal (as determined by ROC curve analysis). The cut-offs for lipids in accordance with NCEP guidelines. ${ }^{38}$ were: Cholesterol $(220 \mathrm{mg} / \mathrm{dl})$, triglyceride (150mg/dl), HDL-C (40mg/dl), LDL-C (130mg/dl), nonHDL-C $(160 \mathrm{mg} / \mathrm{dl})$. One or more abnormal serum lipid biomarker concentration was regarded as dyslipidemia. ${ }^{38}$ 
Table I Anthropometric and biochemical characteristics of study subjects

\section{Non-diabetic healthy controls $(\mathbf{N}=544)$}

\begin{tabular}{|c|c|c|}
\hline \multicolumn{3}{|c|}{ Anthropometric data(Mean $\pm S D)$} \\
\hline Age(Years) & $56.88 \pm 10.44^{*}$ & $48.82 \pm|2.9|$ \\
\hline $\operatorname{BMI}\left(\mathrm{Kg} / \mathrm{m}^{2}\right)$ & $27.28 \pm 5.14^{*}$ & $26.01 \pm 4.68$ \\
\hline WHR & $0.93 \pm 0.11 *$ & $0.91 \pm 0.07$ \\
\hline \multicolumn{3}{|c|}{ Biochemical Parameters(Mean $\pm S D$ ) } \\
\hline $\mathrm{FPG}(\mathrm{mg} / \mathrm{dl})$ & $139.62 \pm 48.37 *$ & $88.89 \pm 12.68$ \\
\hline $\mathrm{HbAlc}(\%)$ & $8.14 \pm 1.77^{*}$ & $5.70 \pm 0.52$ \\
\hline $\mathrm{FI}(\mu \mathrm{lU} / \mathrm{ml})$ & $10.77 \pm 6.52 \$$ & II. $.89 \pm 5.40$ \\
\hline HOMA-IR & $3.74 \pm 3.33^{*}$ & $2.67 \pm 1.54$ \\
\hline $\mathrm{TC}(\mathrm{mg} / \mathrm{dl})$ & $176.92 \pm 51.42$ & $180.98 \pm 46.49$ \\
\hline $\mathrm{TG}(\mathrm{mg} / \mathrm{dl})$ & $|4| .28 \pm 73.55^{*}$ & $\mathrm{I} 12.79 \pm 53.57$ \\
\hline HDL-C(mg/dl) & $53.86 \pm 16.66 @$ & $56.40 \pm 17.19$ \\
\hline LDL-C(mg/dl) & 94.32+49.28@ & $101.43 \pm 45.20$ \\
\hline Non-HDL-C(mg/dl) & $126.48 \pm 52.34$ & $124.59 \pm 47.23$ \\
\hline
\end{tabular}

$@ p<0.02 ;{ }^{*}<0.001 ; \$ p<0.002$

\section{Results}

Assessment of baseline anthropometric and biochemical characteristics

There were $50.95 \%$ males. $\mathrm{N}=535(\mathrm{~N}=273$ T2DM, $\mathrm{N}=262$ non diabetic healthycontrols) and $49.05 \%$ females. $\mathrm{N}=515 \quad(\mathrm{~N}=233$ T2DM, N=282 non diabetic healthy controls) from amongst a total of 1050 study subjects. Base line anthropometric and biochemical characteristics are summarized in Table 1. The mean duration of diabetes amongst the T2DM subjects was 8.62years (range: 6months to 40years) and had significantly higher FPG, HbA1c, HOMA-IR, TG and significantly lower FI, HDL-C, LDL-C as compared to controls (non-diabetic healthy individuals), while no differences were seen in
TC and non-HDL-C amongst the two subgroups. T2DM subjects had also a higher BMI (Body Mass Index) and WHR (Waist to hip ratio) than controls.

\section{Allelic polymorphism rs I 80 I 282 of PPAR $\gamma 2$ gene}

The overall frequency of $\mathrm{C}$ allele (Pro, Reference allele) of rs1801282 of PPAR 2 gene in the study cohort was $0.90(81.41 \%$, $\mathrm{N}=852$ ) while frequency of $\mathrm{G}$ allele (Ala, Variant allele) was $0.10(18.86 \%, \mathrm{~N}=198$; Figure 1). There was a uniform distribution of both alleles in the study subjects by Hardy-Weinberg equilibrium $(\mathrm{p}=1.0, \mathrm{df}=1)$. The Pro allele had a frequency of $0.91(83.40 \%, \mathrm{~N}=422)$ in T2DM and $0.89(79.04 \%, \mathrm{~N}=430)$ in controls while the Ala allele had a frequency of $0.09(16.60 \%, \mathrm{~N}=84)$ in $\mathrm{T} 2 \mathrm{DM}$ and $0.11(20.96 \%$, $\mathrm{N}=114$ ) in controls respectively. Considering the lower frequency of Ala12Ala allele in T2DM $(0.01 \%, \mathrm{~N}=5)$ and in control subjects $(0.01 \%, \mathrm{~N}=7)$ respectively, subjects with Pro12Ala (heterozygous) and Ala12Ala (homozygous) were grouped together for further analysis. The frequencies of Pro (reference) and Ala (variant) allele were not different in the current study similar to Finnish, Spanish, North- and South- Indian subset populations; while in other populations, the frequencies were significantly different (Figure 1).

\section{Allelic polymorphism rs4994 of ADRß3 gene}

The overall frequency of A (Trp, Reference allele) allele rs4994 of $A D R \beta 3$ gene in the study population was $0.91(82.86 \%, \mathrm{~N}=870)$ while the frequency of G (Arg, Variant allele) allele was $0.09(17.14 \%$, $\mathrm{N}=180$; Figure 2). Both alleles showed a uniform distribution in the study subjects by Hardy-Weinberg equilibrium $(\mathrm{p}=0.740, \mathrm{df}=1)$. The Trp allele showed a frequency of 0.89 in T2DM $(81.03 \%, \mathrm{~N}=410)$ and 0.92 in control subjects $(84.56 \%, \mathrm{~N}=460)$ while Arg allele showed a frequency of 0.11 in T2DM $(16.79 \%, \mathrm{~N}=85)$ and 0.08 in control subjects $(14.89 \%, \mathrm{~N}=81)$. Considering the low frequency of Arg64Arg allele in T2DM $(0.02 \%, \mathrm{~N}=11)$ and in control subjects $(0.01 \%, \mathrm{~N}=3)$ respectively, those with Trp64Arg (heterozygous) and Arg 64 Arg (homozygous) were grouped together for further analysis. The reported frequencies of Trp (reference) and Arg (variant) allele were no different in the present study similar to Han Chinese (Beijing), Chinese in Denver (USA), Gujarati Indian (Houston), Japanese (Tokyo), Mexican (LA, USA), Masai in Kenya, Spanish and significantly different in other population subsets (Figure 1).

Supplementary Table

\begin{tabular}{|c|c|c|c|c|c|c|c|c|}
\hline \multirow[b]{2}{*}{ SNP ID } & \multirow[b]{2}{*}{ Primers(forward \& reverse) } & \multicolumn{3}{|c|}{ PCR conditions } & \multirow{2}{*}{$\begin{array}{l}\text { No. of } \\
\text { PCR } \\
\text { cycles }\end{array}$} & \multirow{2}{*}{$\begin{array}{l}\text { Restriction } \\
\text { enzyme } \\
\text { used for } \\
\text { RFLP }\end{array}$} & \multirow[b]{2}{*}{$\begin{array}{l}\text { Digested } \\
\text { product allele }\end{array}$} & \multirow[b]{2}{*}{$\begin{array}{l}\text { Product } \\
\text { size }\end{array}$} \\
\hline & & & $\begin{array}{l}\text { Temp. } \\
\left({ }^{\circ} \mathrm{C}\right)\end{array}$ & $\begin{array}{l}\text { Time } \\
\text { (sec) }\end{array}$ & & & & \\
\hline & & & & & & Method & & \\
\hline \multirow{3}{*}{$\begin{array}{l}\text { rs- } \\
|80| 282\end{array}$} & 5'-ACTCTGGGAGATTCTCCTATTGGC-3' & Denaturation & 94 & 20 & & & $\begin{array}{l}\text { Wild } \\
\text { Type(Pro I2Pro) }\end{array}$ & $132+23 b p$ \\
\hline & \multirow[t]{2}{*}{ 5'-CTGGAAGACAAACTACAAGAG-3' } & Annealing & 56 & 20 & $\begin{array}{l}28 \\
\text { Cycles }\end{array}$ & Haelll & $\begin{array}{l}\text { Heterozygous } \\
\text { Variant(Pro I 2Ala) }\end{array}$ & $\begin{array}{l}155+132 \\
23 \mathrm{bp}\end{array}$ \\
\hline & & Extension & 72 & 20 & & & $\begin{array}{l}\text { Homozygous } \\
\text { Variant(Ala I2Ala) }\end{array}$ & $155 \mathrm{bp}$ \\
\hline \multirow{3}{*}{ rs-4994 } & 5'-CGCCCAATACCGCCAACAC-3' & Denaturation & 94 & 30 & & & $\begin{array}{l}\text { Wild } \\
\text { type(Trp64Trp) }\end{array}$ & $152+58 \mathrm{bp}$ \\
\hline & \multirow[t]{2}{*}{ 5'-CCACCAGGAGTCCCATCACC-3' } & Annealing & 69 & 30 & $\begin{array}{l}32 \\
\text { Cycles }\end{array}$ & Mspl & $\begin{array}{l}\text { Heterozygous } \\
\text { Variant(Trp64Arg) }\end{array}$ & $\begin{array}{l}82+70+ \\
58+152 b p\end{array}$ \\
\hline & & Extension & 72 & 30 & & & $\begin{array}{l}\text { Homozygous } \\
\text { Variant(Arg64Arg) }\end{array}$ & $\begin{array}{l}82+70+ \\
58 \mathrm{bp}\end{array}$ \\
\hline
\end{tabular}




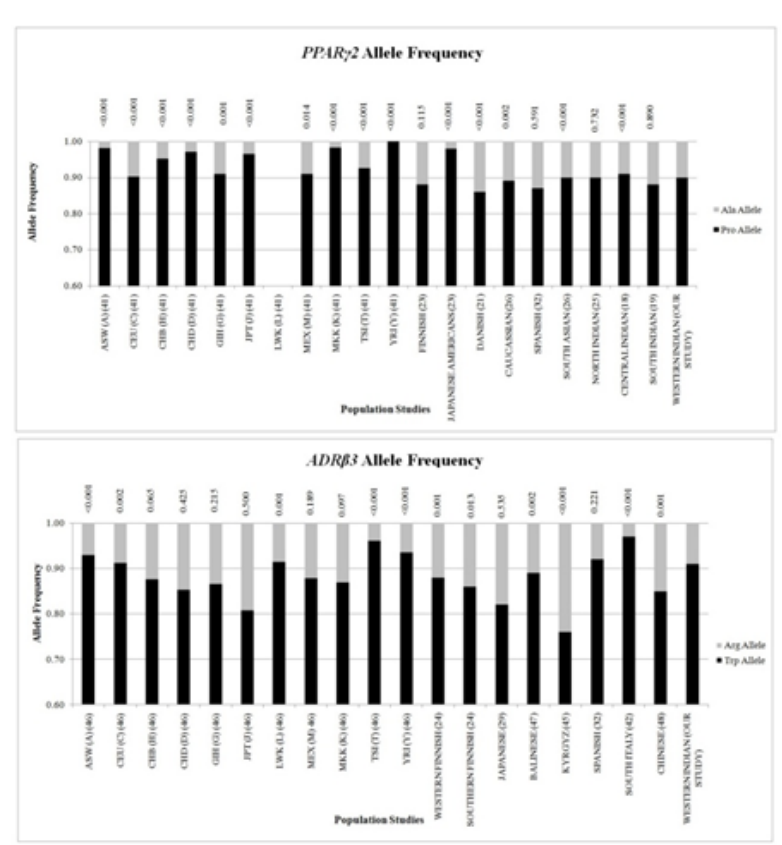

Figure I Comparison of allelic frequencies of rsI80I282 of PPAR 2 gene and rs4994 of $A D R \beta 3$ gene.

\section{Association of allelic polymorphism of rs I 801282 and rs4994 with T2DM risk}

rs1801282and rs4994 were processed through logistic regression to identify their association with increased or decreased T2DM risk. However, we could not find any significant association of T2DM with variant allele of $P P A R \gamma 2$ gene $(\mathrm{OR}=0.85,95 \% \mathrm{CI}: 0.63-1.14, \mathrm{p}=0.27)$, but the presence of the variant allele of $A D R \beta 3$ gene was significantly associated with an increased risk of T2DM (OR=1.48, 95\% CI: 1.10 $2.00, \mathrm{p}=0.01$ ).

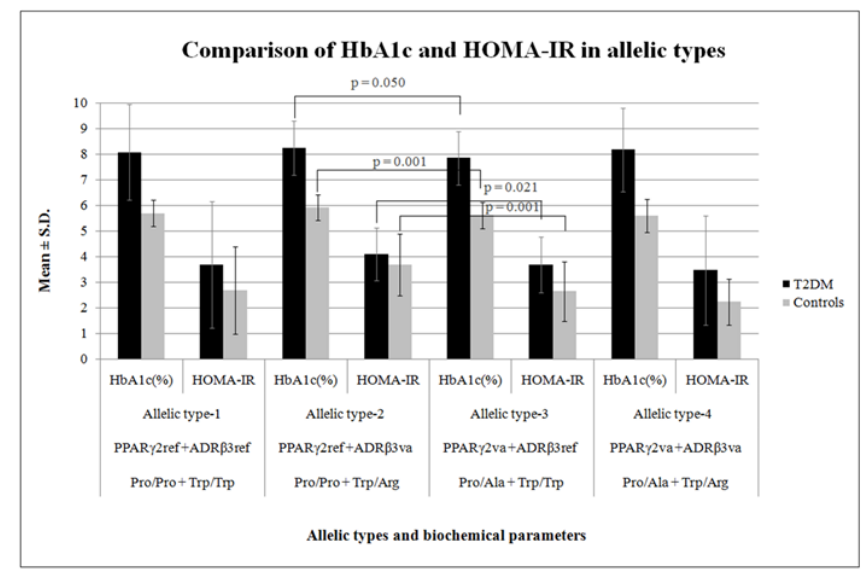

Figure 2 Comparison of allelic combinations of rs I80I282 of PPAR 2 gene and rs4994 of $A D R \beta 3$ gene with $\mathrm{HbAlc}$ and HOMA-IR.

\section{Association of allelic polymorphism of rs I 80 I 282 and rs4994 to biochemical parameters}

HbA1c and HOMA-IR were similar in diabetics bearing reference allele. (PPAR 2 ; Pro/Pro) or $(A D R \beta 3$; Trp/Trp) or variant allele. (PPAR 2 gene; Pro/Ala) or (ADR 33 gene; Trp/Arg). Control subjects with $P P A R \gamma 2$ reference allele had significantly higher $(\mathrm{p}=0.04) \mathrm{HbA} 1 \mathrm{c}$ (though in the normal range) as compared to PPAR 2 variant allele announcing a possibility of its diabetogenic role. In contrast, control subjects bearing $A D R \beta 3$ reference allele had significantly lower HbA1c. Though in the normal range $(\mathrm{p}=0.05)$ than controls harboring variant $A D R \beta 3$ allele suggesting a likelihood of its protective role (Table 2).

Table 2 Influence of allelic polymorphism on $\mathrm{HbAlc}$ and Insulin resistance

\section{PPARG2}

\begin{tabular}{lllll}
\hline & & & \multicolumn{2}{c}{$\begin{array}{l}\text { Non-diabetic healthy } \\
\text { controls }\end{array}$} \\
\hline & $\begin{array}{l}\text { Reference } \\
\text { Allele Pro/ } \\
\text { Pro(N=422) }\end{array}$ & $\begin{array}{l}\text { Variant } \\
\text { Allele Pro/ } \\
\text { Ala(N=84) }\end{array}$ & $\begin{array}{l}\text { Reference } \\
\text { Allele Pro/ } \\
\text { Pro(N=430) }\end{array}$ & $\begin{array}{l}\text { Variant } \\
\text { Allele Pro/ } \\
\text { Ala(N=114) }\end{array}$ \\
& & & & \\
HbAIc(\%)@ & $8.16 \pm 1.82$ & $8.01 \pm 1.47$ & $5.72 \pm 0.52^{*}$ & $5.62 \pm 0.06^{*}$ \\
HOMA-IR@ & $3.76 \pm 2.45$ & $3.66 \pm 2.67$ & $2.68 \pm 1.63$ & $2.62 \pm 1.13$
\end{tabular}

\section{ADRB3}

$\begin{array}{llll}\text { Reference } & \text { Variant } & \text { Reference } & \text { Variant } \\ \text { Allele Trp/ } & \text { Allele Trp/ } & \text { Allele Trp/ } & \text { Allele Trp/ } \\ \operatorname{Trp}(\mathrm{N}=410) & \operatorname{Arg}(\mathrm{N}=96) & \operatorname{Trp}(\mathrm{N}=460) & \operatorname{Arg}(\mathrm{N}=84)\end{array}$

$\mathrm{HbAlc}(\%) @ \quad 8.4 \pm \mathrm{I} .80 \quad 8.15 \pm \mathrm{I} .60 \quad 5.68 \pm 0.52 * * \quad 5.80 \pm 0.52 * *$

HOMA-IR@ $3.68 \pm 2.53 \quad 4.00 \pm 2.64 \quad 2.68 \pm I .60 \quad 2.63 \pm 1.16$

@ Values expressed as Mean \pm SD

$* \mathrm{p}=0.04 ; * * \mathrm{p}=0.05$

When presence or absence of dyslipidemia was added to both diabetics and non-diabetic controls, dyslipidemic diabetic individuals with reference $P P A R \gamma 2$ allele had significantly higher $\mathrm{HbA} 1 \mathrm{c}$ $(\mathrm{p}=0.048$; Linear regression: $\mathrm{r} 2=0.102, \mathrm{p}<0.0010)$ and HOMA-IR $(\mathrm{p}=0.001)$ than variant bearing dyslipidemic diabetic individuals (Table 3). Amongst the non-dyslipidemic diabetics also, a similar observation was evident. Higher HbA1c $(\mathrm{p}=0.001)$ and HOMA-IR $(\mathrm{p}=0.043)$ in $P P A R \gamma 2$ reference allele bearing individuals than variant $P P A R \gamma 2$ bearing individuals, (Table 3 ). Collectively these results point towards a diabetogenic role of PPAR 2 reference allele than the variant allele amongst diabetic subjects. Control subjects on the other hand, did not show such difference in HbA1c or HOMA-IR.

$A D R \beta 3$ variant allele bearing dyslipidemic diabetic individuals exhibited a higher HOMA-IR ( $\mathrm{p}=0.005$; Linear regression: $\mathrm{r} 2=0.057$, $\mathrm{p}=0.019$ ) than the reference $A D R \beta 3$ allele bearing dyslipidemic diabetics suggesting a possible connection of variant allele to dyslipidemia and diabetogenicity; while such a difference was not seen in non-dyslipidemic diabetics. Control subjects did not show such difference (Table 3). 
Table 3 Influence of allelic polymorphism and lipid status on hemoglobin glycation and insulin resistance

\begin{tabular}{|c|c|c|c|c|c|}
\hline & & T2DM & & $\begin{array}{l}\text { Non-diabetic healthy } \\
\text { controls }\end{array}$ & \\
\hline & & Dyslipidemia & & & \\
\hline & & PPARG2 & & & \\
\hline & & Reference Allele & Variant Allele & $\begin{array}{l}\text { Reference Allele Pro/ } \\
\text { Pro(N=205) }\end{array}$ & $\begin{array}{l}\text { Variant Allele Pro/ } \\
\mathrm{Ala}(\mathrm{N}=57)\end{array}$ \\
\hline & & Pro/Pro(N=225) & Pro/Ala $(\mathrm{N}=4 \mathrm{I})$ & & \\
\hline \multirow[t]{2}{*}{$\mathrm{HbAlc}(\%)$} & $\begin{array}{l}\text { Mean } \pm \\
\text { SD }\end{array}$ & $8.27 \pm 1.63 *$ & $7.74 \pm 1.24 *$ & $5.77 \pm 0.50$ & $5.65 \pm 0.51$ \\
\hline & R2 & $0.102 t$ & 0.053 & 0.011 & 0.111 \\
\hline \multirow[t]{5}{*}{ HOMA-IR } & $\begin{array}{l}\text { Mean } \pm \\
\text { SD }\end{array}$ & $4.06 \pm 1.49 * *$ & $3.24 \pm 1.32 * *$ & $2.77 \pm 1.84$ & $2.7 I \pm I .0 I$ \\
\hline & $\mathrm{R} 2$ & 0.004 & 0.006 & 0.072 & 0.172@ \\
\hline & & ADRB3 & & & \\
\hline & & Reference Allele & Variant Allele & Reference Allele & Variant Allele \\
\hline & & $\operatorname{Trp} / \operatorname{Trp}(\mathrm{N}=209)$ & $\operatorname{Trp} / \operatorname{Arg}(\mathrm{N}=57)$ & $\operatorname{Trp} / \operatorname{Trp}(\mathrm{N}=220)$ & $\operatorname{Trp} / \operatorname{Arg}(\mathrm{N}=240)$ \\
\hline \multirow[t]{2}{*}{$\mathrm{HbAlc}(\%)$} & $\begin{array}{l}\text { Mean } \pm \\
\text { SD }\end{array}$ & $8.28 \pm 1.72$ & $8.33 \pm 1.76$ & $5.75 \pm 0.5 \mathrm{I}$ & $5.88 \pm 0.54$ \\
\hline & R2 & 0.098 & 0.019 & $0.087^{* *}$ & 0.085 \\
\hline \multirow[t]{6}{*}{ HOMA-IR } & $\begin{array}{l}\text { Mean } \pm \\
\text { SD }\end{array}$ & $3.84 \pm 1.99 \$$ & $4.61 \pm 1.02 \$$ & $2.75 \pm 1.78$ & $2.80 \pm 1.21$ \\
\hline & $\mathrm{R} 2$ & $0.057 \Omega$ & 0.031 & 0.013 & 0.059 \\
\hline & & No Dyslipidemia & & & \\
\hline & & PPARG2 & & & \\
\hline & & $\begin{array}{l}\text { Reference } \\
\text { Allele }\end{array}$ & Variant Allele Pro/Ala(N=43) & $\begin{array}{l}\text { Reference Allele Pro/ } \\
\text { Pro(N=225) }\end{array}$ & $\begin{array}{l}\text { Variant allele Pro/ } \\
\mathrm{Ala}(\mathrm{N}=57)\end{array}$ \\
\hline & & Pro/Pro(N=197) & & & \\
\hline \multirow[t]{2}{*}{ HbAIc(\%) } & $\begin{array}{l}\text { Mean } \pm \\
\text { SD }\end{array}$ & $8.17 \pm 1.68 * *$ & $7.26 \pm 1.63^{* *}$ & $5.68 \pm 0.53$ & $5.58 \pm 0.54$ \\
\hline & R2 & 0.044 & 0.161 & $0.095 t$ & 0.024 \\
\hline \multirow[t]{5}{*}{ HOMA-IR } & $\begin{array}{l}\text { Mean } \pm \\
\text { SD }\end{array}$ & $3.64 \pm 1.74 \#$ & $3.06 \pm 1.49 \#$ & $2.6 I \pm I .4 I$ & $2.53 \pm 1.24$ \\
\hline & R2 & 0.011 & $0.285 \mathrm{~W}$ & 0.012 & 0.113 \\
\hline & & ADRB3 & & & \\
\hline & & $\begin{array}{l}\text { Reference } \\
\text { Allele }\end{array}$ & Variant Allele & Reference Allele & Variant Allele \\
\hline & & $\begin{array}{l}\text { Trp/Trp } \\
\mathrm{N}=20 \mathrm{I})\end{array}$ & $\operatorname{Trp} / \operatorname{Arg}(\mathrm{N}=39)$ & $\operatorname{Trp} / \operatorname{Trp}(\mathrm{N}=240)$ & $\operatorname{Trp} / \operatorname{Arg}(\mathrm{N}=42)$ \\
\hline \multirow[t]{2}{*}{ HbAlc(\%) } & Mean $\pm S D$ & $7.76 \pm 1.28$ & $8.01 \pm 1.87$ & $5.62 \pm 0.52$ & $5.7 I \pm 0.47$ \\
\hline & $\mathrm{R}^{2}$ & 0.018 & $0.392 \Delta$ & $0.066 \propto$ & 0.212 \\
\hline \multirow[t]{2}{*}{ HOMA-IR } & Mean $\pm S D$ & $3.09 \pm 2.22$ & $3.54 \pm 1.99$ & $2.45 \pm 1.05$ & $2.61 \pm 1.42$ \\
\hline & $\mathrm{R}^{2}$ & $0.072 \delta$ & 0.232 & 0.026 & 0.054 \\
\hline
\end{tabular}

Linear Regression(LR) mentioned as $\mathrm{R}^{2}$

P values: $* 0.048 ; * * 0.001 ; \$ 0.005 ;{ }^{*} 0.043 ;{ }^{\star} 0.000 ;{ }^{@} 0.040 ;{ }^{\Omega} 0.019 ;{ }^{\circ} 0.002 ;{ }^{\propto} 0.003 ;{ }^{8} 0.012$.

Assessment of rsl80I282 and rs4994 allelic 2: PPAR $2 \mathrm{ref}+A D R \beta 3 \mathrm{va}$ (Pro/Pro+Trp/Arg); Allelic typecombinations with biochemical characteristics

rs1801282 of PPAR 2 gene and rs4994 of ADRß3 gene allelic combinations yielded four allelic types. Allelic type1: PPAR 2 ref $+A D R \beta 3$ ref $\quad($ Pro/Pro+Trp/Trp); Allelic type-

3: PPAR $2 \mathrm{va}+A D R \beta 3 \mathrm{ref} \quad($ Pro/Ala + Trp/Trp); Allelic type-4: $P P A R \gamma 2 \mathrm{va}+A D R \beta 3 \mathrm{va}$ (Pro/Ala + Trp/Arg). For assessment of interactions, we dichotomized biochemical parameters viz. HbAlc, HOMA-IR into normal/high and lipid status into dyslipidemia/nondyslipidemia. $\mathrm{HbA} 1 \mathrm{c} \geq 7.0 \%$ in $\mathrm{T} 2 \mathrm{DM}$ and $\mathrm{HbA} 1 \mathrm{c} \geq 5.7 \%$ in controls 
was regarded as high in accordance with IDF recommendations. 22The cut-off of HOMA-IR(3.95) was determined on ROC analysis. Specificity: $87.8 \%$ (95\% CI:84.7-90.4\%); sensitivity: $32.45 \%$ (95\% CI:28.3-36.8); +LR:2.66 (95\% CI:2.1-3.4); -LR: 0.77 (95\% CI:0.70.8); +PV:77.7\%; -PV:58.9\%; Supplementary Figure 1.

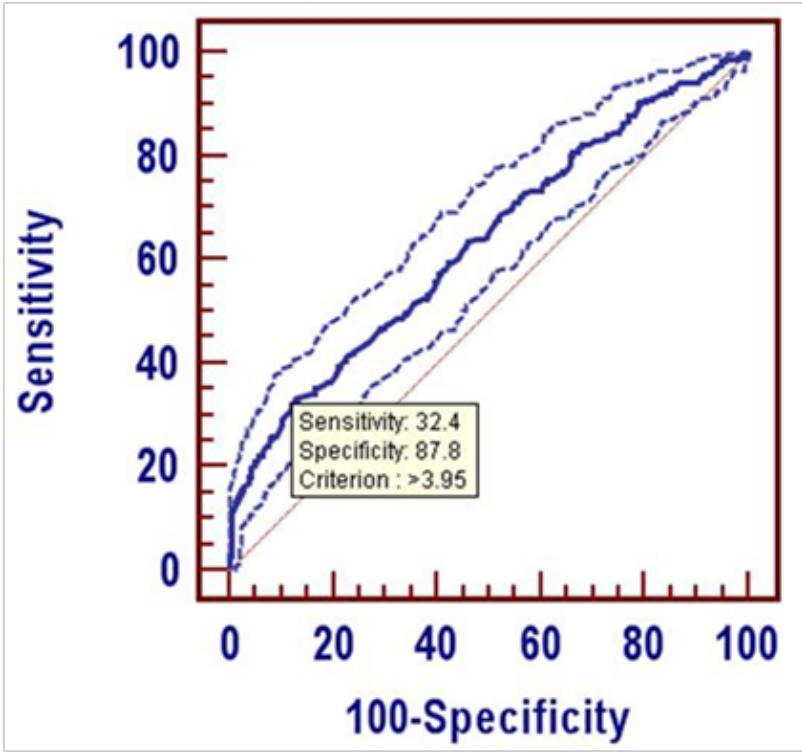

Supplementary Figure I.

We compared the Mean \pm SD of HbA1c and HOMA-IR with aforementioned four allelic combinations. A higher HbAlc and HOMA-IR was seen in allelic combination-2 as compared to combination-3 (HbA1c:T2DM p=0.050, Controls $\mathrm{p}=0.001$ ) and (HOMA-IR: T2DM $\mathrm{p}=0.021$, Controls $\mathrm{p}=0.001$ ); Figure 2] suggesting a likelihood of association of PPAR 2 ref and $A D R \beta 3 \mathrm{va}$ alleles with poor glycation and insulin resistance in our study population.

When presence or absence of dyslipidemia was added to these allelic combinations, allelic type-2 bearing T2DM individuals but not control individuals had higher HbAlc $(p=0.042)$ and HOMAIR $(p=0.002)$ than allelic type-3 (Figures 3A\&B). Similarly, nondyslipidemic individuals with allelic type-2 also demonstrated higher HbA1c (T2DM p=0.033; Controls $\mathrm{p}=0.001$ ) and HOMA-IR (T2DM $\mathrm{p}=0.010$; Controls $\mathrm{p}=0.001$ ) than individuals (both diabetics and controls) with allelic type- 3 again suggesting a likelihood of association of reference allele of PPAR 2 gene and variant allele of $A D R \beta 3$ gene to poor glycation and insulin resistance.

We further elaborated our results with binary logistic regression model. Where all these bifurcated (low/high; dyslipidemic/nondyslipidemic) biochemical parameters were juxtaposed and compared to all six possible combinations of allelic types (Table 4). Again, presence of high HbA1c. $\mathrm{p}=0.034$; LR (Likelihood Ratio): 4.559, $\mathrm{p}=0.033$ and dyslipidemia. $\mathrm{p}=0.012$; LR: 6.372, $\mathrm{p}=0.012$ were significantly connected to allelic type-2. On the other hand, higher HOMA-IR was seen in all allelic combinations with type-4. Higher $\operatorname{Exp}(\mathrm{B})$ between

a. Allelic type-1 vs allelic type-4 (LR: 3.870, p=0.049),

b. Allelic type-2 vs allelic type-4 (LR: $3.675, \mathrm{p}=0.055$ ), and

c. Allelic type-3 vs allelic tye-4 (LR: 5.808, p=0.016); Table 4 possibly suggesting a connection of $A D R \beta 3$ variant allele to higher HOMA-IR.
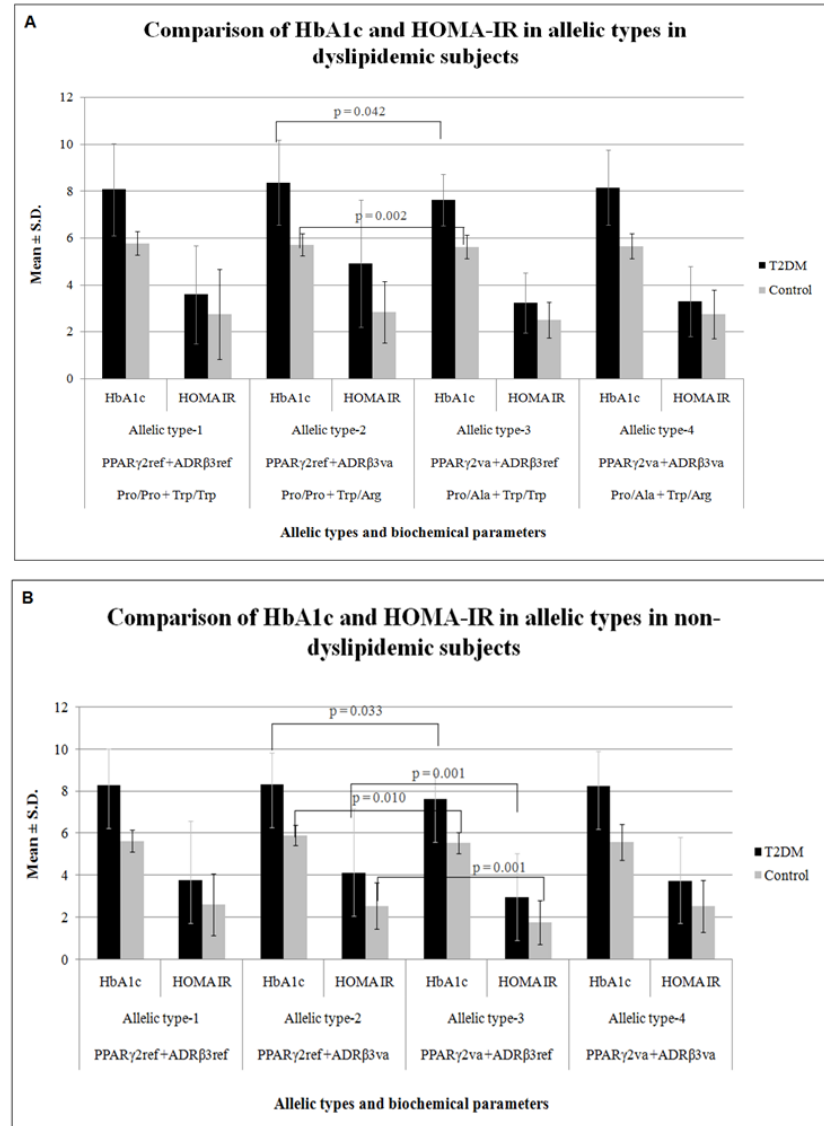

Figure 3 Comparison of allelic combinations of rs 1801282 of PPARy2gene and rs4994 of $A D R \beta 3$ gene with HbAlc and HOMA-IR in dyslipidemic and non-dyslipidemic subjects.

Table 4 Interactions of allelic combinations with glycated hemoglobin, HOMA-IR and lipid status

\begin{tabular}{|c|c|c|c|}
\hline & & & Logistic regression \\
\hline & & & $\operatorname{Exp}(B)$ \\
\hline Allelic type-I & $\mathrm{HbAlc}(\%)$ & Normal & 1.362 \\
\hline vs & & High & 1.296 \\
\hline \multirow[t]{4}{*}{ Allelic type-2 } & HOMA-IR & Normal & 1.152 \\
\hline & & High & 0.977 \\
\hline & Lipid Status & & I.145 \\
\hline & & $\begin{array}{l}\text { Dyslipidemia } \\
\text { Dyslipidemia }\end{array}$ & \\
\hline Allelic type-I & $\mathrm{HbAlc}(\%)$ & Normal & 0.785 \\
\hline vs & & High & 0.909 \\
\hline \multirow[t]{4}{*}{ Allelic type-3 } & HOMA-IR & Normal & 0.888 \\
\hline & & High & 0.736 \\
\hline & Lipid Status & $\begin{array}{l}\text { No } \\
\text { Dyslipidemia }\end{array}$ & 0.897 \\
\hline & & Dyslipidemia & 0.772 \\
\hline Allelic type-I & $\mathrm{HbAlc}(\%)$ & Normal & 1.029 \\
\hline vs & & High & 1.17 \\
\hline \multirow[t]{2}{*}{ Allelic type-4 } & HOMA-IR & Normal & 1.084 \\
\hline & & High & 857.944 \\
\hline
\end{tabular}


Table Continues...

\begin{tabular}{|c|c|c|c|}
\hline & & & Logistic regression \\
\hline & & & $\operatorname{Exp}(B)$ \\
\hline & \multirow[t]{2}{*}{ Lipid Status } & $\begin{array}{l}\text { No } \\
\text { Dyslipidemia }\end{array}$ & 1.168 \\
\hline & & Dyslipidemia & 1.111 \\
\hline Allelic type-2 & \multirow[t]{2}{*}{$\mathrm{HbAlc}(\%)$} & Normal & 0.814 \\
\hline vs & & High & $0.452^{*}$ \\
\hline \multirow[t]{4}{*}{ Allelic type-3 } & \multirow[t]{2}{*}{ HOMA-IR } & Normal & 0.685 \\
\hline & & High & 0.554 \\
\hline & \multirow[t]{2}{*}{ Lipid Status } & $\begin{array}{l}\text { No } \\
\text { Dyslipidemia }\end{array}$ & 0.838 \\
\hline & & Dyslipidemia & $0.449 * *$ \\
\hline \multirow[t]{2}{*}{ Allelic type-2 } & \multirow[t]{2}{*}{$\mathrm{HbAlc}(\%)$} & Normal & 0.943 \\
\hline & & High & 1.255 \\
\hline \multirow[t]{4}{*}{ Allelic type-4 } & \multirow[t]{2}{*}{ HOMA-IR } & Normal & 1.103 \\
\hline & & High & 25420.27 \\
\hline & \multirow[t]{2}{*}{ Lipid Status } & $\begin{array}{l}\text { No } \\
\text { Dyslipidemia }\end{array}$ & 1.289 \\
\hline & & Dyslipidemia & 1.017 \\
\hline \multirow[t]{2}{*}{ Allelic type-3 } & \multirow[t]{2}{*}{$\mathrm{HbAlc}(\%)$} & Normal & 1.967 \\
\hline & & High & 1.936 \\
\hline \multirow[t]{4}{*}{ Allelic type-4 } & \multirow[t]{2}{*}{ HOMA-IR } & Normal & 1.614 \\
\hline & & High & $1.17 \mathrm{E}+09$ \\
\hline & \multirow[t]{2}{*}{ Lipid Status } & $\begin{array}{l}\text { No } \\
\text { Dyslipidemia }\end{array}$ & 1.983 \\
\hline & & Dyslipidemia & 2.688 \\
\hline
\end{tabular}

$*_{p}=0.034 ; *_{p}=0.012$

Allelic type-I: PPARG2ref+ADRB3ref(Pro/Pro+Trp/Trp);

Allelic type-2: PPARG2ref+ADRB3va(Pro/Pro+Trp/Arg);

Allelic type-3: PPARG2va+ADRB3ref(Pro/Ala+Trp/Trp);

Allelic type-4: PPARG2va+ADRB3va(Pro/Ala+Trp/Arg).

\section{Discussion}

T2DM is the most common complex metabolic disorder influenced by genetic, environmental and lifestyle factors. Although the causes of T2DM cannot be pinpointed, many studies have shown a strong genetic link. ${ }^{20,39}$ to interactions of several candidate genes as an underlying etiology. ${ }^{25,26}$ rs 1801282 of nuclear receptor PPAR 2 stimulates transcription of several genes implicated in adipogenesis, lipid metabolism and insulin signaling and might possibly affect insulin resistance. Alanine ( $\mathrm{G}$ allele, variant allele) is shown to favor $\alpha$-helix formation of PPAR 2 gene product and activate amino terminal resulting into activation of ligand-independent transcription. Conversely, Proline (C allele, reference allele) modulates $\alpha$-helix formation in a manner that predisposes to insulin resistance. ${ }^{20,21,23}$ Thus, the variant allele is likely to have a protective role in insulin resistance, pathophysiology of T2DM and dyslipidemia. A study reported the relation of Ala allele of PPAR 2 gene to lower the T2DM risk in Caucasians, and in over weight subjects it was found to be associated with lower insulin with increased insulin sensitivity. ${ }^{22}$ Conversely, the Pro allele of $P P A R \gamma 2$ gene is likely to increase insulin resistance and subsequent dyslipidemia in a meta-analysis. ${ }^{40}$ The authors reported a frequency of Ala (variant allele) in the range of $8.0 \%$ to $51 \%$ in Caucasians (a subset of entire population). HAPMAP reported frequency of Ala (Variant) allele is in the range of 0 to $10 \%$. We observed a frequency of Ala (variant) allele similar to GIH (Gujarati Indians in Houston, Texas, 9.09\%) population of HAPMAP. ${ }^{41}$ We observed that $79.80 \%(\mathrm{~N}=158 / 198)$ individuals bearing variant allele of PPAR 2 had HOMA-IR below ROC cutoff supporting the previous reports of its likely association to insulin sensitivity. Conversely, high HOMA-IR (>ROC cut-off) was observed in 188/852 (22.06\%) individuals bearing reference allele favoring its association to insulin resistance irrespective of the diabetic status. Two studies reported an association of Ala allele to reduced binding affinity to promoter elements and reduced ability to transactivate response elements of the responsive genes and improved insulin sensitivity. ${ }^{23}$ and reduced risk of insulin resistance with reduced TG levels in non-diabetics. ${ }^{21}$ Though in the current study, we did not observe differences in incidence of dyslipidemia amongst diabetics and controls bearing Ala allele of PPAR 2 gene. Mohan et al5 also concluded that despite the frequency of the Ala allele at the PPARgPro12Ala locus being the same in individuals of South Asian descent, as in Caucasians, this particular polymorphism does not appear to improve insulin sensitivity or decrease risk for type 2 diabetes in South Asians (Asian Indians), as it does in Caucasians.

Nonetheless, all dyslipidemic individuals of our study with Pro allele of PPAR 2 gene had higher HbA1c and HOMA-IR than those with Ala allele (of $P P A R \gamma 2$ gene) again favouring a likely association of this variant to predisposition for poor glycation and insulin resistance. A meta-analysis exhibited Ala allele of $P P A R \gamma 2$ gene, to confer a risk reduction of T2DM by $21 \% .{ }^{17}$ Thus, there has been a consensus that $P P A R \gamma 2$ variant allele confers 'protection' against T2DM and its likely manifestations in the form of reduced insulin resistance, reduced BMI and decreased lipid parameters. Conversely, presence of reference allele of PPAR 2 gene has an opposite effect. Similarly, a study performed on South Asians (a subset of entire population) concluded that variant allele of PPAR 2 gene does not offer any protective role. ${ }^{26}$

$A D R \beta 3$ gene variant (rs4994) product, largely found in visceral adipocytes regulate lipolysis and mediate catecholamine induced cAMP activation by G-proteins. ${ }^{24}$ The exact mechanism of $A D R \beta 3$ gene in modulation of insulin secretion is not known, but glucose stimulated insulin secretion from pancreatic $\beta$ cells is known to be potentiated by epinephrine. Lower levels of cAMP with variant allele of $A D R \beta 3$ gene in pancreatic $\beta$ cells may reduce insulin release. ${ }^{24}$ Polymorphism of aforesaid gene (A allele, Trp64Arg) is shown to be associated to abdominal obesity and insulin-resistance. ${ }^{24,42,43}$ Visceral obesity is also known to be associated with reduced FFA uptake and impaired insulin action that result into insulin resistance in skeletal muscle due to higher free fatty acids (FFA) or triglycerides. ${ }^{42,43}$ Present study demonstrate significant association of variant allele rs4994 of $A D R \beta 3$ gene with an increased risk of T2DM, most likely to be due to higher HOMA-IR in dyslipidemic T2DM patients. The variant allele of $A D R \beta 3$ gene is also reported to be linked to insulin resistance in obese Italian males. ${ }^{44}$ and metabolic syndrome (obesity and low HDL-C) in Kyrgyz people. ${ }^{45}$ HAPMAP reported frequencies of reference- (A allele) and variant ( $\mathrm{G}$ allele) alleles of rs4994 of $A D R \beta 3$ gene ranges from $80-96 \%$ and $3.9-19.1 \%$ respectively. We found a relatively higher frequency of variant allele (17.14\%) similar to HAPMAP population of CHB (H). Han Chinese in Beijing, China; $12.40 \%$, CHD (D). Chinese in Metropolitan Denver, Colorado; $14.67 \%$, GIH (G). Gujarati Indians in Houston, Texas; $13.36 \%$, JPT (J). Japanese in Tokyo, Japan; 19.19\%, MEX (M). Mexican ancestry in Los Angeles, California; $12.04 \%$ and MKK (K). Masai in Kinyawa, Kenya; $13.14 \%{ }^{46-48}$ This allele is reported to be connected to insulin resistance in a meta-analysis of 31 studies. ${ }^{44}$ 
While juxtaposing aforementioned alleles to link IR, T2DM and dyslipidemia, we observed a significantly higher $\mathrm{HbA1c}$, increased IR and dyslipidemia in individuals with allelic type- 2 compared to allelic type-3. This point towards a possibility that co-existence of reference allele of PPAR 2 gene and variant allele of $A D R \beta 3$ gene in an individual may predispose to develop biochemical deregulation connected to T2DM, poor hemoglobin glycation, dyslipidemia and subsequent metabolic syndrome. Likewise, co-existence of reference allele of $A D R \beta 3$ gene and variant allele of PPAR 2 gene is likely to be protective against T2DM. A similar finding has been reported by Moon et al. in Korean population. ${ }^{49}$

The present study has also shown the likelihood of high HOMAIR when allelic type- 4 was present compared to type- 1 to type 3 . As shown by high $\operatorname{Exp}(\mathrm{B})$ on logistic regression. A similar report by Ochoa et al. also demonstrated higher BMI, serum leptin and insulin with co-existence of variants of PPAR 2 gene and ADR 33 gene. ${ }^{32}$

Coexistence of alleles in population is a natural phenomenon. Such allelic combinations along with life style predisposition may trigger epigenomic changes by increased DNA methylation of the genes and hold a clue to design tailored diagnostic, therapeutic and preventive efforts to control or subvert the disease. The functionality of the resultant proteins and their impact on metabolic pathways is greatly modified by epigenetic studies and protein-protein interaction. The allelic interactions reported here need further insight into epigenetics of these allelic combinations in pathophysiology of T2DM..$^{32,33,50}$

\section{Conclusion}

The present study demonstrate that coexistence of reference allele of PPAR 22 gene and variant allele of $A D R \beta 3$ gene together with dyslipidemia in subjects with T2DM is likely to confer poor hemoglobin glycation and increased insulin resistance; thus demonstrating a likelihood of T2DM predisposition in western Indian population.

\section{Acknowledgments}

None.

\section{Conflicts of interest}

The author declares that there are no conflicts of interest.

\section{Funding}

None.

\section{References}

1. McCarthy M, Menzel S. The genetics of type 2 diabetes. Br J Clin Pharmacol. 2001;51(3):195-199.

2. Hansen T. Genetics of Type 2 diabetes. Current Science. 2002;83(12):1477-1482.

3. McCarthy MI, Froguel P. Genetic approaches to the molecular understanding of type 2 diabetes. Am J Physiol Endocrinol Metab. 2002;283(2):E217-E225.

4. Altshuler D, Hirschhorn JN, Klannemark M, et al. The common PPARgamma Pro12Ala polymorphism is associated with decreased risk of type 2 diabetes. Nat Genet. 2000;26(1):76-80.

5. Radha V, Mohan V. Genetic predisposition to type 2 diabetes among Asian Indians. Indian J Med Res. 2007;125(3):259-274.
6. Unnikrishnan R, Anjana RM, Mohan V. Diabetes mellitus and its complications in India. Nat Rev Endocrinol. 2016;12(6):357-370.

7. Mohan V, Sharp PS, Cloke HR, et al. Serum immunoreactive insulin responses to a glucose load in Asian Indian and European Type 2 (noninsulin-dependent) diabetic patients and control subjects. Diabetologia. 1986;29(4):235-237.

8. Ramachandran A, Snehalatha C, Viswanathan V, et al. Risk of non insulin dependent diabetes mellitus conferred by obesity and central adiposity in different ethnic groups: a comparative analysis between Asian Indians, Mexican Americans and Whites. Diabetes Res Clin Pract. 1997;36(2):121-125.

9. Chandalia M, Abate N, Garg A, et al. Relationship between generalized and upper body obesity to insulin resistance in Asian Indian men. J Clin Endocrinol Metab. 1999;84(7):2329-2335.

10. Raji A, Seely EW, Arky RA, et al. Body fat distribution and insulin resistance in healthy Asian Indians and Caucasians. J Clin Endocrinol Metab. 2001;86(11):5366-5371.

11. Banerji MA, Faridi N, Atluri R, et al. Body composition, visceral fat, leptin and insulin resistance in Asian Indian men. J Clin Endocrinol Metab. 1999;84(1):137-144.

12. Mc Keigue PM, Shah B, Marmot MG. Relation of central obesity and insulin resistance with high diabetes prevalence and cardiovascular risk in South Asians. Lancet. 1991;337(8738):382-386.

13. Mc Keigue PM, Pierpoint T, Ferrie JE, et al. Relationship of glucose intolerance and hyperinsulinaemia to body fat pattern in south Asians and Europeans. Diabetologia. 1992;35(8):785-71.

14. Abate N, Chandalia M. The impact of ethnicity on type 2 diabetes. $J$ Diabetes Complications. 2003;17:39-58.

15. Abate N, Garg A, Peshock RM, et al. Relationships of generalized and regional adiposity to insulin sensitivity in men. J Clin Invest. 1995;96(1):88-98.

16. Joshi R. Metabolic syndrome-Emerging clusters of the Indian Phenotype. J Assoc Physicians India. 2003;51:445-446.

17. Stumvoll M, Häring H. The Peroxisome Proliferator-Activated Receptor$\gamma 2$ Pro12Ala Polymorphism. Diabetes. 2002;51(8):2341-2347.

18. Tripathi AK, Shukla S, Dwivedi MK, et al. Type 2 diabetes in a central Indian population: association with PPARG2 P121A allele but not ENPP1 K121Q. Advances in Genomics and Genetics. 2013;3:1-9.

19. Sailaja K, Bhatnagar P. PPARG polymorphism and their association with Type 2 Diabetes in South Indian population. International Journal of Pharmacy Technology. 2010;2(3):623-633.

20. Luan J, Browne PO, Harding AH, et al. Evidence for gene-nutrient interaction at the PPAR $\gamma$ locus. Diabetes. 2001;50(3):686-689.

21. Frederiksen L, Brødbaek K, Fenger M, et al. Studies of the Pro12Ala Polymorphism of the PPAR $-\gamma$ Gene in the Danish MONICA Cohort: Homozygosity of the Ala Allele Confers a Decreased Risk of the Insulin Resistance Syndrome. J Clin Endocrinol Metab. 2002;87(8):3989-3992.

22. Huguenin GV, Rosa G. The Ala allele in the PPAR-g2 gene is associated with reduced risk of type 2 diabetes mellitus in Caucasians and improved insulin sensitivity in overweight subjects. Br J Nutr. 2010;104(4):488-497.

23. Deeb SS, Fajas L, Nemoto M, et al. A Pro12Ala substitution in PPARgamma2 associated with decreased receptor activity, lower body mass index and improved insulin sensitivity. Nat Genet. 1998;20(3):284-287.

24. Widén E, Lehto M, Kanninen T, et al. Association of a polymorphism in the $b 3$-Adrenergic receptor gene with features of the insulin resistance 
syndrome in Finns. N Engl J Med. 1995;333(6):348-351.

25. Sanghera DK, Ortega L, Han S, et al. Impact of nine common type 2 diabetes risk polymorphisms in Asian Indian Sikhs: PPARG2 (Pro12Ala), IGF2BP2, TCF7L2 and FTO variants confer a significant risk. $B M C$ Medical Genet. 2008;9(59):1-9.

26. Radha V, Vimaleswaran KS, Babu HN, Abate N, Chandalia M, et al. Role of Genetic Polymorphism Peroxisome Proliferator-Activated Receptor$\gamma 2$ Pro12Ala on Ethnic Susceptibility to Diabetes in South-Asian and Caucasian Subjects. Diabetes Care. 2006;29(5):1046-1051.

27. Cruz M, Valladares-Salgado A, Garcia-Mena J, et al. Candidate gene association study conditioning on individual ancestry in patients with type 2 diabetes and metabolic syndrome from Mexico City. Diabetes Metab Res Rev. 2010;26(4):261-270.

28. McFarlane-Anderson N, Bennett F, Wilks R, et al. The Trp64Arg mutation of the beta3-adrenergic receptor is associated with hyperglycemia and current body mass index in Jamaican women. Metabolism. 1998;47(5):617-621.

29. Oizumi T, Daimon M, Saitoh T, et al. Funagata Diabetes Study. Genotype Arg/Arg, but not Trp/Arg, of the Trp64Arg polymorphism of the beta (3)-adrenergic receptor is associated with type 2 diabetes and obesity in a large Japanese sample. Diabetes Care. 2001;24(9):1579-1583.

30. Gjesing AP, Andersen G, Borch-Johnsen K, et al. Association of the beta3-adrenergic receptor Trp64Arg polymorphism with common metabolic traits: studies of 7605 middle-aged white people. Mol Genet Metab. 2008;94:90-97.

31. Kurokawa N, Young EH, Oka Y, et al. The ADRB3 Trp64Arg variant and BMI: a meta-analysis of 44833 individuals. Int J Obes (Lond). 2008;32(8):1240-1249.

32. Ochoa MC, Marti A, Azcona C, et al. Groupo de Estudio Navarro de ObesidadInfantil (GENOI). Gene-gene interaction between PPAR gamma 2 and ADR beta 3 increases obesity risk in children and adolescents. Int $J$ Obesity. 2004;28(S3):S37-S41.

33. Hsueh WC, Cole SA, Shuldiner AR, et al. Interactions between variants in the beta3-adrenergic receptor and peroxisome proliferatoractivated receptor-gamma 2 genes and obesity. Diabetes Care. 2001;24(4):672-677.

34. Matthews DR, Hosker JP, Rudenski AS, et al. Homeostasis model assessment: Insulin resistance and $\beta$-cell function from fasting plasma glucose and insulin concentrations in man. Diabetologia. $1985 ; 28(7): 412-419$.

35. Miller S, Dykes D, Polesky H. A simple salting out procedure for extracting DNA from human nucleated cells. Nucleic Acids Research. $1988 ; 16(3): 1215$.
36. www.biostats.usc.edu/software

37. Vikram NK, Jialal I. Use of HbA1c in the diagnosis of diabetes and pre-diabetes: sensitivity versus specificity. Metab Syndr Relat Disord. 2014;12(5):255-257.

38. Executive summary of the Third Report of The National Cholesterol Education Program (NCEP) Expert Panel on detection, evaluation, and treatment of high blood cholesterol in adults (Adult Treatment Panel III). JAMA. 2001;285(19):2486-2497.

39. Fonseca V. Defining and Characterizing the Progression of Type 2 Diabetes. Diabetes Care. 2009;32(2):S151-156.

40. Goodarzi MO, Guo X, Taylor KD, et al. Lipoprotein lipase is a gene for insulin resistance in Mexican Americans. Diabetes. 2004;53(1):214-220.

41. Bracale R, Pasanisi F, Labruna G, et al. Metabolic syndrome and ADRB3 gene polymorphism in severely obese patients from South Italy. Eur $J$ Clin Nutr. 2007;61(10):1213-1219.

42. Thomas GN, Tomlinson B, Chan JCN, et al. The Trp64Arg polymorphism of the b3-adrenergic receptor gene and obesity in Chinese subjects with components of the metabolic syndrome. Int J Obesity. 2000;24(5):545-551

43. Fujisawa T, Ikegami H, Kawaguchi Y, et al. Meta-analysis of the association of Trp64Arg polymorphism of beta 3-adrenergic receptor gene with body mass index. J Clin Endocrinol Metab. 1988;83(7):2441-2444.

44. Mirrakhimov AE, Kerimkulova AS, Lunegova OS, et al. An association between TRP64ARG polymorphism of the B3 adrenoreceptor gene and some metabolic disturbances. Cardiovascular Diabetology. 2011;10:89.

45. Malik SG, Saraswati MR, Suastika K, et al. Association of beta3adrenergic receptor (ADRB3) Trp64Arg gene polymorphism with obesity and metabolic syndrome in the Balinese: a pilot study. BMC Research Notes. 2011;4:167.

46. Yang M, Huang Q, Wu J, et al. Effects of UCP2-866 G/A and ADRB3 Trp64Arg on rosiglitazone response in Chinese patients with Type 2 diabetes. Br J Clin Pharmacol. 2009;68(1):14-22.

47. Moon MK, Cho YM, Jung HS, et al. Genetic polymorphisms in peroxisome proliferator-activated receptor gamma are associated with Type 2 diabetes mellitus and obesity in the Korean population. Diabet Med. 2005;22(9):1161-1166.

48. Sugii S, Evans RM. Epigenetic Codes of PPAR $\gamma$ in Metabolic Disease. FEBS Lett. 2011;585(13):2121-2128. 